\title{
Analisis Pengambilan Keputusan Taktis Pelaku UMKM (Usaha Mikro, Kecil Dan Menengah) Di Masa Pandemi Covid'19
}

\author{
Tatik \\ Fakultas Bisnis dan Ekonomika, Universitas Islam Indonesia, Yogyakarta \\ Email : 162121302@uii.ac.id
}

\begin{abstract}
This study aims to analyze the tactical decisions of MSME actors during the Covid19 pandemic. This research uses a qualitative approach with a case study method. The data used are primary data sourced from in-depth interviews and direct observation. Research respondents were 5 (five) MSME with different business fields. The results showed that the COVID-19 pandemic had several impacts on MSMEs, namely a decrease in turnover and operating profit, difficulty in distributing goods and uncollectible accounts. The tactical decisions taken by MSME players in order to maintain their business are the implementation of WFH (Work From Home) policies, cutting wages, cutting and delaying the payment of THR (Tunjangan Hari Raya), asking for relaxation and restructuring of bank credit, reducing the amount of production and making product innovations or service.
\end{abstract}

Keywords: Tactical Decisions, MSME, Pandemic Covid'19

\section{Pendahuluan}

Sejarah perekonomian Indonesia mencatat besarnya kontribusi UMKM dalam menghadapi beragam krisis yang mendera negeri ini. Pada masa krisis moneter 1998, UMKM menjadi penyangga ekonomi nasional. Sementara di masa krisis keuangan global 2008, UMKM tetap kuat menopang perekonomian nasional.

Namun kini sektor UMKM kembali diuji ketahanannya ketika virus korona Covid19 merebak sejak akhir 2019 lalu. Sebagian pengamat memperkirakan sektor UMKM akan mengalami kesulitan menahan dampak yang timbul akibat wabah Covid-19 tersebut. UMKM dinilai sebagai sektor yang paling rentan terhadap krisis ekonomi karena Covid19. Pasalnya, jenis usaha ini sangat bergantung pada perputaran uang hasil penjualan barang dagangan.

Dalam sejumlah media diberitakan, pelaku UMKM mulai menghadapi beragam kesulitan bisnis sejak wabah Covid-19 meluas di Tanah Air. Ketua Asosiasi UMKM Indonesia, Ikhsan Ingratubun menyebutkan, omzet UMKM mulai turun sejak Februari 
tahun ini. Kemudian pada bulan Maret, ada sejumlah UMKM yang tidak mendapat pemasukan sama sekali. Bahkan, ada beberapa UMKM yang sampai memberhentikan karyawannya karena kesulitan finansial.

Sektor UMKM yang paling terdampak dari penyebaran virus korona meliputi fashion, kerajinan tangan, jasa transportasi daring, dan kuliner. Kesulitan yang dihadapi antara lain sulitnya penyerapan produk-produk UMKM. Jika masalah ini tak segera ditangani dengan baik, dikhawatirkan akan berdampak pada pemutusan hubungan kerja (PHK) terhadap karyawan.

Pandemi Covid-19 benar-benar memberikan dampak besar pada keberlangsungan bisnis Usaha Kecil dan Menengah (UKM). Berdasarkan hasil survei, sebanyak 96\% pelaku UKM mengaku sudah mengalami dampak negatif Covid-19 terhadap proses bisnisnya. Sebanyak $75 \%$ di antaranya mengalami dampak penurunan penjualan yang signifikan.

Tak hanya itu, 51\% pelaku UKM meyakini kemungkinan besar bisnis yang dijalankan hanya akan bertahan satu bulan hingga tiga bulan ke depan. Sebanyak 67\% pelaku UKM mengalami ketidakpastian dalam memperoleh akses dana darurat, dan 75\% merasa tidak mengerti bagaimana membuat kebijakan di masa krisis. Sementara, hanya 13\% pelaku UKM yakin, mereka memiliki rencana penanganan krisis dan menemukan solusi untuk mempertahankan bisnis mereka (Rizki Caturini, 2020)

Dalam situasi pandemi ini, menurut KemenkopUKM ada sekitar 37.000 UMKM yang memberikan laporan bahwa mereka terdampak sangat serius dengan adanya pandemi ini ditandai dengan sekitar 56 persen melaporkan terjadi penurunan penjualan, 22 persen melaporkan permasalahan pada aspek pembiayaan, 15 persen melaporkan pada masalah distribusi barang, dan 4 persen melaporkan kesulitan mendapatkan bahan baku mentah (Aknolt Kristian Pakpahan, 2020).

Meskipun pemerintah telah berupaya memberikan stimulus untuk meredam dampak Pandemi Covid'19, misalnya program insentif pajak bagi UMKM dan memberikan kemudahan pembayaran kredit bagi UMKM yang terdampak, namun kebijakan tersebut belum mampu mengatasi berbagai persoalan UMKM menghadapi dampak Pandemi Covid'19. Pelaku UMKM juga terus berupaya mempertahankan usaha mereka dengan berbagai strategi.

Beberapa penelitian terdahulu telah memaparkan dampak Pandemi Covid'19 terhadap perekonomian Indonesia maupun berbagai bidang pada Usaha Mikro Kecil dan Menengah. Akan tetapi, penulis tidak menemukan penelitian terdahulu yang menganalisis keputusan strategis pelaku UMKM untuk bertahan menghadapi Pandemi Covid'19. Oleh 
karena itu, maka penulis tertarik untuk melakukan penelitian tentang Analisis Pengambilan Keputusan Taktis Pelaku Usaha Mikro Kecil dan Menengah dalam Menghadapi Pandemi Covid'19.

\section{Rumusan Masalah}

1. Apakah dampak Pandemi Covid'19 terhadap Usaha Mikro Kecil dan Menengah?

2. Apakah keputusan taktis para pelaku Usaha Mikro Kecil dan Menengah dalam upaya mempertahankan usaha mereka menghadapi Pandemi Covid'19?

\section{Tujuan Penelitian}

1. Mengetahui berbagai dampak Pandemi Covid'19 terhadap Usaha Mikro Kecil dan Menengah.

2. Menganalisis keputusan taktis para pelaku Usaha Mikro Kecil dan Menengah dalam upaya mempertahankan usaha mereka menghadapi Pandemi Covid'19.

\section{Tinjauan Pustaka}

\subsection{Usaha Mikro, Kecil dan Menengah}

Sesuai dengan Undang- Undang Nomor 20 Tahun 2008 tentang Usaha Mikro, Kecil dan Menengah (UMKM), Usaha Mikro adalah usaha produktif milik orang perorangan dan/atau badan usaha perorangan yang memenuhi kriteria Usaha Mikro sebagaimana diatur dalam Undang-Undang ini. Usaha Kecil adalah usaha ekonomi produktif yang berdiri sendiri, yang dilakukan oleh orang perorangan atau badan usaha yang bukan merupakan anak perusahaan atau bukan cabang perusahaan yang dimiliki, dikuasai, atau menjadi bagian baik langsung maupun tidak langsung dari usaha menengah atau usaha besar yang memenuhi kriteria Usaha Kecil sebagaimana dimaksud dalam Undang-Undang ini.

Adapun kriteria usaha mikro, kecil dan menengah adalah sbb:

Tabel 2.1Kriteria UMKM

\begin{tabular}{lccc}
\hline \multirow{2}{*}{ No. } & URAIAN & ASSET & OMZET \\
\hline $\mathbf{1}$ & USAHA MIKRO & Maks. 50 Juta & Maks. 300 Juta \\
$\mathbf{2}$ & USAHA KECIL & $>$ 50 Juta - 500 Juta & $>$ 300 Juta - 2,5 Miliar \\
$\mathbf{3}$ & USAHA MENENGAH & $>$ 500 Juta - 10 Miliar & $>$ 2,5 Miliar - 50 Miliar \\
\hline \multicolumn{4}{c}{ sumber:www.depkop.go.id }
\end{tabular}

Rentang kuantitatif seperti dijelaskan dalam pasal 6 dalam UU No 20 Tahun 2008, bahwa kriteria UMKM adalah sebagai berikut: 
a. Usaha Mikro: memiliki aset bersih (tidak termasuk tanah dan bangunan) maksimum Rp50.000.000 atau memiliki penjualan tahunan maksimum Rp300.000.000;

b. Usaha Kecil: memiliki aset bersih (tidak termasuk tanah dan bangunan) antara Rp50.000.000 dan Rp500.000.00 atau memiliki penjualan tahunan antara Rp300.000.000 hingga Rp2.500.000.000;

c. Usaha Menengah: memiliki aset bersih (tidak termasuk tanah dan bangunan) antara Rp500.000.000 dan Rp10.000.000.000 atau memiliki penjualan tahunan antara Rp2.500.000.000 dan Rp50.000.000.000.

\subsection{Pandemi Covid'19 dan Dampaknya terhadap Usaha Mikro Kecil dan Menengah}

Sejak kemunculannya di akhir tahun 2019, virus Covid-19 telah menyebar di seluruh dunia. Dengan cepatnya penyebaran Covid-19, dampak perlambatan ekonomi global mulai dirasakan di dalam negeri. Antonius Purwanto menyebutkan, pada masa covid'19 ini harga minyak bumi jatuh ke arah terendah sejak 1991, bursa saham terjun bebas, serta harga komoditas lain seperti gas dan minyak sawit diperkirakan juga akan tertarik ke bawah apabila permintaan tidak segera pulih (Kompas, 11 Maret 2020).

Berdasarkan data yang diolah P2E LIPI, penurunan pariwisata akibat pandemi covid'19 terhadap UMKM yang bergerak dalam usaha makanan dan minuman mikro mencapai $27 \%$. Sedangkan dampak terhadap usaha kecil makanan dan minuman sebesar 1,77\%, dan usaha menengah di angka 0,07\%. Pengaruh virus Covid-19 terhadap unit kerajinan dari kayu dan rotan, usaha mikro akan berada di angka 17,03\%. Untuk usaha kecil di sektor kerajinan kayu dan rotan $1,77 \%$ dan usaha menengah $0,01 \%$. Sementara itu, konsumsi rumah tangga juga akan terkoreksi antara $0,5 \%$ hingga $0,8 \%$.

\subsection{Keputusan Taktis}

Keputusan taktis merupakan keputusan manajemen perusahaan yang bersifat jangka pendek. Menurut Slamet Sugiri Sogirin (2015), beberapa keputusan taktis antara lain:

1. Menerima atau menolak pesanan khusus

Pesanan khusus adalah pesanan di luar penjualan normal, biasanya dengan harga lebih rendah daripada harga jual normal. Dalam jangka pendek dan masih ada kapasitas yang menganggur, penentuan harga jual dapat mempertimbangkan differential cost.

2. Menambah atau memperhentikan departemen atau produk

Produk lama mungkin mulai pudar ketenarannya karena ada perubahan preferensi konsumen sehingga produk lama tersebut tidak menguntungkan lagi dan diperlukan produk baru sebagai pengganti. Keputusan mengganti produk atau departemen harus 
dilakukan secara hati-hati agar dapat meningkatkan laba perusahaan.

3. Membeli dari luar atau memproduksi sendiri

Keputusan membeli dari luar atau memproduksi sendiri sering dihadapi oleh manajemen pada perusahaan pabrikasi yang membuat suatu produk dengan menggunakan beberapa suku cadang. Dilema keputusan terjadi karena perusahaan mampu memproduksi sendiri sementara di produk atau suku cadang tersebut juga tersedia di pasar.

4. Memproses setelah split-off point atau langsung menjual

Beberapa produk dihasilkan secara bersamaan dari bahan baku yang sama atau dari proses produksi yang sama. Dalam akuntansi produk tersebut disebut joint-product. Saat joint product tersebut dapat dipisahkan disebut split off point. Dalam kasus tertentu, setelah split off point satu atau lebih produk dapat dijual langsung atau dapat pula diproses lebih lanjut.

5. Memilih produk

Perusahaan juga sering dihadapkan pada pemilihan satu produk agar laba bisa optimal.

Pilihan yang menguntungkan adalah memilih produk yang memberikan margin kontribusi tertinggi.

\section{Metode Penelitian}

\subsection{Metode Penelitian}

Metode penelitian merupakan cara utama yang digunakan peneliti untuk mencapai tujuan dan menentukan jawaban atas masalah yang diajukan. Sugiyono (2014) berpendapat bahwa metode penelitian merupakan cara ilmiah untuk mendapatkan data dengan tujuan dan kegunaan tertentu.

Penelitian ini menggunakan metode kualitatif dengan pendekatan studi kasus yang menghasilkan data deskriptif; ucapan atau tulisan dan perilaku yang diamati dari orang-orang (subyek) itu sendiri. Dan hasil penelitian kualitatif ini lebih menekankan makna daripada generalisasi. Studi kasus menurut Yin (2008) adalah suatu inquiri empiris yang menyelidiki fenomena dalam konteks kehidupan nyata, bilamana batas-batas antar fenomena dan konteks tak tampak dengan tegas dan dimana multisumber bukti dimanfaatkan.

\subsection{Spesifikasi dan Sumber Data Penelitian}

Spesifikasi penelitian ini bersifat deskriptif, karena penelitian ini merupakan suatu upaya untuk mendiskripsikan berbagai dampak Pandemi Covid'19 terhadap UMKM dan keputusan taktis pelaku UMKM atas berbagai dampak tersebut. Selanjutnya, dilakukan 
pembahasan dan analisis sehingga dapat diambil kesimpulan.

Data yang digunakan pada penelitian ini adalah data primer yang bersumber dari dokumen wawancara kepada beberapa pelaku UMKM terkait dan observasi (pengamatan) langsung untuk memperoleh informasi yang lebih lengkap dan akurat terkait dokumen tersebut.

\subsection{Analisis Data}

Analisis data kualitatif adalah upaya yang dilakukan dengan jalan bekerja dengan data, mengorganisasikan data, memilah-milahnya menjadi satuan yang dapat dikelola, mensintesiskannya, mancari dan menemukan pola, menemukan apa yang penting dan apa yang dipelajari, dan memutuskan apa yang dapat diceritakan kepada orang lain. Analisis data dilakukan sepanjang penelitian ini dan dilakukan secara terus menerus dari awal sampai akhir penelitian. Proses penelitian ini berbentuk siklus meliputi pengumpulan data, display data, reduksi data, dan penarikan kesimpulan (Miles, M.B, Huberman, A.M, \& Saldana, J. 2014).

\section{Hasil Dan Pembahasan}

\subsection{Hasil Analisis Data}

\subsubsection{Dampak Pandemi Covid'19 terhadap Kondisi UMKM}

Pandemi covid'19 membawa pengaruh yang sangat besar terhadap perkembangan usaha. Usaha Mikro Kecil dan Menengah juga merasakan dampak dari pandemi covid tersebut. Sebagian besar dunia industri menjadi lesu karena penurunan permintaan barang.

\section{UMKM yang Bergerak dalam Bidang Fashion}

Pada masa pandemi, masyarakat lebih memfokuskan belanja pada kebutuhan rumah tangga, terutama bahan pokok sehari-hari dan produk kesehatan, sehingga belanja pada sektor lain, termasuk fashion mengalami penurunan.

UMKM yang bergerak dalam bidang fashion merasakan dampak pandemi covid'19 pada usahanya. Omset usaha turun berkisar 30-40\% tiap bulan di masa pandemi. Penurunan omset, menurut keterangan pemilik UMKM, disebabkan karena menurunnya permintaan barang serta karena kebijakan PSBB (Pembatasan Sosial Berskala Besar) yang diberlakukan oleh pemerintah. Kebijakan PSBB tersebut berdampak pada kesulitan distribusi barang karena eksepedisi membatasi layanan pengiriman barang ke berbagai wilayah terdampak pandemi.

\section{UMKM yang Bergerak dalam Bidang Event Organizer}

Jasa utama pada UMKM ini adalah memberikan layanan pengelolaan event atau kegiatan. Kebijakan PSBB (Pembatasan Sosial Berskala Besar) yang diberlakukan oleh 
pemerintah mengharuskan seluruh event yang mengumpulkan massa dalam jumlah besar dihentikan. Otomatis kegiatan UMKM juga berhenti secara total.

Tidak hanya mengalami penurunan omset, pemilik UMKM mengaku tidak ada pemasukan sama sekali dari usahanya, atau dengan kata lain omset usaha menjadi nol. Seluruh proyek event yang direncanakan batal dilaksanakan. Selain itu, pemilik UMKM mengeluhkan seluruh piutang usaha kepada para konsumen tidak bisa ditagih.

\section{UMKM yang Bergerak dalam Bidang Jasa Digital}

Pada masa pandemi, sebagian besar pelaku usaha mengeluhkan penurunan omset. Namun, UMKM yang bergerdak dalam bidang jasa digital ini mengalami kondisi yang berkebalikan. Pemilik UMKM mengaku, usahanya justru mengalami peningkatan. Kebutuhan jasa digital, baik pembuatan website dan layanan iklan online di media sosial semakin bertambah banyak di masa pandemi.

Peningkatan kebutuhan jasa digital di masa pandemi berdampak pada kenaikan omset UMKM sekitar 50\% tiap bulan atau sebesar Rp 45.000.000. Klien UMKM merupakan pemilik usaha yang bergerak dalam bidang kuliner, fashion, pendidikan, layanan kesehatan dan instansi pemerintah.

\section{UMKM yang Bergerak dalam Bidang Konveksi}

Produk utama dari UMKM ini adalah pembuatan pakaian seragam untuk instansi pemerintah atau organisasi swasta. Selain melayani pembuatan pakaian seragam, UMKM juga melayani pembuatan pakaian dalam skala besar maupun kecil.

Pada masa pandemi, pemilik UMKM mengatakan usahanya mengalami penurunan. Omset usaha turun rata-rata 40\% atau sebesar Rp 28.000.000 per bulan. Selain penurunan omset, dampak lain yang dirasakan adalah kenaikan harga bahan baku berupa kain hingga mencapai 3 (tiga) kali lipat. Hal ini tentu berpengaruh terhadal laba usaha yang semakin menurun. Di sisi lain, UMKM yang bergerak dalam bidang konveksi ini menangkap adanya peluang untuk memproduksi kebutuhan APD (Alat Pelindung Diri) baik masker maupun pakaian khusus bagi tenaga kesehatan.

\section{UMKM yang Bergerak dalam Bidang Penyedia Kebutuhan Masjid}

Kebijakan PSBB (Pembatasan Sosial Berskala Besar) yang diterapkan oleh pemerintah berlaku untuk semua jenis kegiatan di masyarakat, tak terkecuali kegiatan di tempat ibadah termasuk masjid. Kegiatan sholat berjama'ah sempat dilarang di beberapa wilayah terdampak pandemi. Jikapun ada masjid yang masih melaksanakan sholat berjama'ah, jumlah jama'ah dibatasi dengan menerapkan jaga jarak. Takmir masjid dihimbau untuk menggulung karpet masjid selama masa pandemi untuk mengurangi 
penularan covid diantara para jama'ah.

Penjualan karpet masjid merupakan produk utama UMKM ini. Berhentinya kegiatan di masjid dan kebijakan tidak memakai karpet masjid sangat berpengaruh terhadap usaha utama UMKM. Permintaan karpet masjid menurun drastis, bahkan di bulan April Juli tidak ada permintaan barang dari konsumen. Omset penjualan yang semula berkisar Rp 350.000.000 turun menjadi Rp 181.000.000. Penurunan omset rerata 50-60\% pada masa pandemi.

\subsubsection{Analisis Keputusan Taktis Pelaku UMKM}

Keputusan taktis merupakan keputusan manajemen perusahaan untuk memilih satu pilihan atau alternatif yang menguntungkan dari berbagai alternatif yang ada. Keputusan taktis yang biasanya diambil oleh manajemen perusahaan yaitu keputusan membuat sendiri atau membeli sebuah komponen, keputusan tetap membuat atau menghentikan lini produk, keputusan menerima tau menolak pesanan khusus dengan harga lebih rendah dari harga regular, dan keputusan mengolah lebih lanjut produk bersama atau menjualnya pada titik pemisahan produk (Krismiaji dan Y Anni Aryani, 2011).

Pada masa pandemi covid'19 ini, pelaku usaha lebih banyak dihadapkan pada keputusan taktis tetap memproduksi produk dalam jumlah regular atau mengurangi jumlah produksi, keputusan tetap beroperasi pada produk atau jasa regular atau mengganti produk atau jasa baru, dan keputusan tetap beroperasi pada jam kerja normal atau mengurangi jam kerja, dan keputusan tetap mempekerjakan karyawan atau menghentikan karyawan.

\section{UMKM yang Bergerak dalam Bidang Fashion}

Lesunya industri bidang fashion pada masa pandemi berdampak pada permintaan barang yang menurun pada UMKM ini. Keputusan taktis yang diambil oleh pemilik UMKM yaitu mengurangi jumlah produksi pakaian muslim. Pada tahun-tahun sebelumnya, moment Romadhan dan lebaran merupakan puncak tertinggi permintaan barang. Namun pandemi covid'19 ini mengubah drastis permintaan barang di bulan puasa dan lebaran.

Meskipun mengalami penurunan sekitar 30\%-40\%, tidak ada pengurangan gaji dan tunjangan bagi karyawan. Pemilik UMKM tetap memberikan gaji dan THR (Tunjangan Hari Raya) penuh tanpa pengurangan. Jam kerja karyawan juga tidak ada pengurangan. Karyawan tetap bekerja di homestore pada hari Senin - Sabtu mulia pukul 08.00 - 16.00 WIB.

UMKM ini juga menambah produk berupa masker dan APD (Alat Pelindung Diri) bagi tenaga medis. Namun penambahan omset dari produk baru tersebut tidak berdampak significant pada penambahan omset usaha. 


\section{UMKM yang Bergerak dalam Bidang Event Organizer}

Berhentinya aktivitas utama usaha pada UMKM yang bergerak dalam bidang event organizer ini memaksa pemilik UMKM untuk mengambil beberapa kebijakan taktis guna menyelamatkan keuangan perusahaan. Selama masa pandemi, pemilik UMKM mengaku telah menambah cash sebesar Rp 45.000.000 untuk menutup operasional kantor.

Beberapa keputusan taktis diambil oleh pemilik UMKM di masa pandemi. Pertama, menerapkan WFH (Work From Home) bagi seluruh karyawan. WFH berlangsung selama 4 (empat) bulan di awal masa pandemi. Kedua, pengurangan gaji karyawan di bulan ke-4 (empat) masa pandemi, sedangkan pada bulan 1-3 gaji masih tetap. Ketiga, pemberian (THR) Tunjangan Hari Raya ditunda dan akan dicairkan sebagai bonus akhir tahun. Keempat, inovasi pengelolaan event menjadi event yang dilakukan secara online. Kelima, meminta restrukturisasi angsuran pada bank untuk menekan pengeluaran kas.

Selain beberapa keputusan taktis di atas, pemilik UMKM juga berupaya menambah pemasukan dengan cara menjual produk kecantikan seperti pelembab wajah, pembersih wajah, lipstick, make up cleansing water dan vitamin untuk menjaga daya tahan tubuh di masa covid.

\section{UMKM yang Bergerak dalam Bidang Jasa Digital}

UMKM yang bergerak dalam bidang jasa digital justru mengalami peningkatan omset di masa pandemi, sehingga tidak ada kebijakan khusus yang diambil oleh pemilik UMKM. Karyawan tetap bekerja normal di kantor dengan menerapkan protokol kesehatan, seperti memakai masker, rajin cuci tangan dan menjaga jarak. Gaji dan THR (Tunjangan Hari Raya) juga tetap diberikan kepada karyawan tanpa ada pengurangan.

Meskipun permintaan jasa digital semakin meningkat di masa pandemi, pemilik UMKM tidak mengambil keputusan untuk penambahan order secara berlebihan karena tenaga kerja terbatas dan khawatir pekerjaan tidak dapat ditangani dengan baik.

\section{UMKM yang Bergerak dalam Bidang Konveksi}

Keputusan menambah produk berupa masker dan APD (Alat Pelindung Diri) langsung diambil oleh pemilik UMKM selama masa pandemi. Kebijakan tersebut cukup membantu menyelamatkan keuangan usaha disaat produksi pakaian seragam menurun hingga $40 \%$.

Keputusan taktis lain yang diambil oleh pemilik UMKM yaitu pengurangan THR (Tunjangan Hari Raya) sebesar $40 \%$ dari tahun lalu. Sementara gaji karyawan masih diberikan penuh. Tidak ada pengurangan jam kerja, karyawan masuk kerja seperti biasa dengan menerapkan protokol kesehatan. Dalam rangka menjaga imunitas karyawan, 
pemilik UMKM memberikan suplemen vitamin senilai Rp 75.000 untuk tiap karyawan per bulan.

Pemilik UMKM juga meminta relaksasi pembayaran angsuran pinjaman kepada bank. Meskipun omset menurun cukup tajam, pemilik UMKM mengaku masih mendapatkan keuntungan dari usaha dan tidak terjadi kerugian.

\section{UMKM yang Bergerak dalam Bidang Penyedia Kebutuhan Masjid}

Pembatasan aktivitas di masjid dan aturan sebagian besar takmir masjid untuk menggulung atau tidak memakai karpet masjid, menjadikan sumber pemasukan terbesar UMKM ini menurun hingga 51\%. Pada tiga bulan awal masa pandemi, sekitar bulan Februari - April 2020, perusahaan masih mencatat laba bersih positif setiap bulannya. Namun pada bulan Mei hingga saat ini, perusahaan mengalami kerugian usaha.

Beberapa keputusan taktis diambil oleh manajemen perusahaan guna mempertahankan usaha. Pertama, pada tiga bulan awal masa pandemi, seluruh karyawan bekerja dari rumah dan mengurangi $50 \%$ gaji pokok karyawan. Hal tersebut juga berdampak pada pengurangan pengeluaran tunjangan makan, transport dan lembur karyawan. Namun manajemen memberikan kompensasi pemberian sembako kepada seluruh karyawan untuk membantu mencukupi kebutuhan pokok keluarga karyawan. Kedua, pembayaran THR (Tunjangan Hari Raya) diberikan secara bertahap, yaitu 2 (dua) kali pencairan, untuk menekan pengeluaran kas. Ketiga, menutup cabang di kota Semarang yang tidak ada transaksi penjualan di masa pandemi. Sementara untuk cabang di kota Klaten dan Purwokerto masih dipertahankan karena masih terdapat transaksi penjualan.

Keempat, menambah mesin untuk mendukung inovasi layanan dry cleaning karpet. Penambahan mesin ini menjadi keputusan yang cukup berat bagi manajemen perusahaan karena menambah pengeluaran kas di saat kondisi keuangan sedang tidak stabil. Namun penambahan mesin dry cleaning ini diharapkan menjadi pendongkrak omset dari layanan cuci karpet, baik untuk kebutuhan masjid, instansi maupun rumah tangga.

\subsection{Pembahasan}

Secara umum, perkembangan bisnis UMKM yang menjadi narasumber penelitian mengalami peningkatan sebelum masa pandemi. Jangkauan pemasaran UMKM juga meluas ke berbagai wilayah di Indonesia. Serapan tenaga kerja yang dikaryakan pun meningkat dari awal usaha.

Namun pada saat pandemi, sebagian besar UMKM mengalami penurunan omset (pendapatan usaha). Hanya satu UMKM yang justru mengalami peningkatan omset, yaitu UMKM yang bergerak dalam bidang jasa digital. Hasil penelitian ini menguatkan 
penelitian sebelumnya yang dilakukan oleh Aknolt Kristian Pakpahan (2020), Eka Budiyanti (2020), Estro Dariatno S (2020), Hanoatubun S (2020), Rail Agis Bahtiar dan Juli Panglima Saragih (2020) terkait dampak covid'19 terhadap bisnis UMKM.

Adapun beberapa dampak pandemi covid'19 pada bisnis UMKM para responden sebagai berikut:

1. Penurunan Omset (Pendapatan Usaha) dan Laba Usaha

Penurunan omset terjadi di UMKM yang bergerak di bidang fashion sebesar 30$40 \%$, UMKM yang bergerak di bidang event organizer sebesar 100\%, UMKM yang bergerak dalam bidang konveksi $40 \%$ dan UMKM yang bergerak dalam bidang penyedia kebutuhan masjid $51 \%$.

Penurunan omset tersebut diiringi penurunan laba usaha yang terjadi di ke-empat UMKM di atas. Bahkan, UMKM yang bergerak di bidang event organizer dan UMKM yang bergerak dalam bidang penyedia kebutuhan masjid mengaku usaha mereka mengalami kerugian.

2. Kesulitan Distribusi Barang

Kesulitan distribusi barang dalam masa pandemi covid'19 disebabkan karena adanya kebijakan PSBB (Pembatasan Sosial Berskala Besar) yang diberlakukan oleh pemerintah. Kebijakan PSBB tersebut mengakibatkan eksepedisi membatasi layanan pengiriman barang bahkan tidak bisa melakukan pengiriman barang ke berbagai wilayah terdampak pandemi. Dampak ini dialami oleh UMKM yang bergerak dalam bidang fashion, yang memiliki reseller dari berbagai wilayah di Indonesia.

3. Piutang Tidak Tertagih

Pemilik UMKM yang bergerak dalam bidang event organizer mengaku kesulitan untuk menagih piutang kepada para konsumen. Lesunya bisnis yang berakibat pada kesulitan memperoleh cash menjadi alasan para konsumen tidak dapat melunasi piutangnya.

Dalam rangka mempertahankan usaha menghadapi dampak pandemi covid'19, pelaku UMKM mengambil beberapa keputusan strategis sebagai berikut:

1. Penerapan kebijakan WFH (Work From Home)

Kebijakan WFH (Work From Home) atau bekerja dari rumah diterapkan oleh UMKM yang bergerak di bidang event organizer pada bulan pertama hingga bulan keempat di awal masa pandemi. Sedangkan UMKM yang bergerak dalam bidang kebutuhan masjid menerapkan kebijakan WFH (Work From Home) pada bulan pertama hingga bulan ketiga 
di awal masa pandemi.

Penerapan kebijakan tersebut selain bertujuan mencegah penularan covid'19 diantara karyawan juga bertujuan untuk mengurangi beban/biaya tunjangan transport karyawan, tunjangan konsumsi karyawan dan beban lembur karyawan.

2. Pengurangan gaji karyawan

Keputusan taktis pengurangan gaji karyawan diterapkan oleh UMKM yang bergerak di bidang event organizer dan UMKM yang bergerak dalam bidang kebutuhan masjid pada bulan ke-empat awal masa pandemi tepatnya di bulan April 2020. Pengurangan gaji pokok tidak langsung diterapkan di bulan Januari 2020 atau pada bulan pertama pandemi karena pelaku/pemilik UMKM masih mencermati trend dampak pandemi terhadap omset usaha.

Pada awal masa pandemi, pelaku UMKM juga masih berupaya mendongkrak penjualan dan berharap omset masih bisa stabil. Namun setelah dicermati selama beberapa bulan omset usaha terus menurun, kedua UMKM memutuskan untuk mengurangi gaji karyawan untuk mengurangi kerugian.

3. Pemotongan atau Penundaan Pembayaran (THR) Tunjangan Hari Raya

Pelaku UMKM yang mengambil keputusan taktis pemotongan (THR) Tunjangan Hari Raya yaitu UMKM yang bergerak dalam bidang konveksi sebesar 40\% dari jumlah pemberian THR tahun 2019. Pemotongan THR ini bertujuan untuk mengurangi pengeluaran biaya, sehingga perusahaan masih bisa mendapatkan laba pada periode yang bersangkutan.

Sedangkan UMKM yang bergerak dalam bidang event organizer menunda pembayaran THR dan akan dibagikan dalam bentuk bonus akhir tahun 2020. Sementara itu, UMKM yang bergerak dalam bidang penyedia kebutuhan masjid melakukan pembayaran THR dalam 2 (dua) kali termin, yaitu di bulan Mei sebesar 50\% dan bulan Juni 2020 sebesar 50\%. Penundaan pembayaran THR dan perubahan metode pembayaran dengan 2 (dua) kali termin dimaksudkan untuk menunda pengeluaran kas.

Pemilik UMKM yang bergerak dalam bidang penyedia kebutuhan masjid mengaku, meskipun usahanya mengalami kerugian, THR tetap dibayarkan penuh kepada karyawan. Hal ini merupakan wujud kepedulian pemilik UMKM agar karyawan masih memperoleh tambahan pemasukan di hari raya umat Islam tersebut.

4. Meminta restrukturisasi dan relaksasi angsuran pada bank

Pemerintah melalui Otoritas Jasa Keuangan (OJK) telah menerbitkan aturan Peraturan Otoritas Jasa Keuangan (POJK) Nomor 11/POJK.03/2020 tentang stimulus 
perekonomian nasional. Tujuan dari diterbitkannya aturan ini adalah untuk memberikan relaksasi kredit bagi nasabah terdampak Covid.

Relaksasi kredit perbankan adalah pelonggaran syarat-syarat kredit, baik syarat financial maupun non financial untuk memberikan kemudahan pada nasabah perbankan. Relaksasi kredit diartikan juga sebagai penundaan jatuh tempo dan perpanjangan jangka waktu (rescheduling) perjanjian kredit. Sedangkan restrukturisasi perjanjian kredit adalah merubah stuktur perjanjian krdit yang memungkinkan terjadi penyesuaian bunga dan re-modelling pembiayaan (Rio Cristiawan, 2020).

Adapun UMKM yang memutuskan untuk meminta relaksasi kredit yaitu UMKM yang bergerak dalam bidang konveksi. Permintaan relaksasi kredit ini bertujuan untuk menunda pengeluaran kas di masa pandemi. Dan UMKM yang bergerak dalam bidang event organizer meminta restrukturisasi kredit atas pinjamannya kepada perbankan agar dapat melakukan efisiensi biaya usaha.

5. Mengurangi jumlah produksi barang

Keputusan taktis mengurangi jumlah produksi barang diterapkan oleh pelaku UMKM yang bergerak dalam bidang fashion. Hal tersebut disebabkan oleh menurunnya permintaan barang berupa pakaian muslim di masa pandemi meskipun bertepatan dengan moment Romadhan dan menjelang lebaran yang biasanya merupakan puncak tertinggi permintaan barang.

6. Melakukan inovasi produk atau jasa baru

Keputusan melakukan inovasi produk atau jasa baru dilakukan oleh UMKM yang bergerak di bidang fashion, UMKM yang bergerak di bidang event organizer, UMKM yang bergerak di bidang konveksi dan UMKM yang bergerak di bidang penyedia kebutuhan masjid.

UMKM yang bergerak di bidang fashion dan UMKM yang bergerak di bidang konveksi melakukan inovasi produk dengan menambah produksi masker dan APD (Alat Pelindung Diri) untuk tenaga medis. Peluang pasar kedua produk tersebut sangat besar dan segera ditangkap oleh kedua UMKM. Kedua UMKM memiliki sumber daya untuk melakukan inovasi produk tersebut, baik mesin, tenaga produksi maupun supplier bahan baku.

Sedangkan UMKM yang bergerak di bidang penyedia kebutuhan masjid melakukan inovasi jasa berupa layanan $d r y$ cleaning karpet masjid. Peningkatan kesadaran akan kebersihan di masa pandemi dijadikan peluang oleh UMKM ini untuk menggencarkan promosi dry cleaning karpet masjid. 
UMKM yang bergerak di bidang event organizer juga melakukan inovasi produk yaitu pengelolaan event secara online. Namun, pendapatan mengelola event online tersebut sangat kecil, tidak sebanding dengan event offline. yang sangat Pelaku UMKM secara pribadi berupaya mencari pemasukan lain yang berbeda jauh dengan bisnis utamanya, yaitu menjual produk kecantikan.

\section{Kesimpulan}

Berdasarkan hasil analisis dan pembahasan yang telah disusun oleh peneliti, peneliti menyimpulkan bahwa:

1. Usaha para pelaku UMKM (Usaha Mikro Kecil dan Menengah) yang menjadi responden penelitian sebelum terjadi pandemi covid'19 berkembang cukup baik. Hal tersebut diindikasikan dari meluasnya jangkauan pemasaran, bertambahnya tenaga kerja yang diberdayakan dan pembukaan cabang-cabang baru.

2. Pandemi covid' 19 memberikan beberapa dampak kepada para pelaku UMKM, yaitu penurunan omset dan laba usaha, kesulitan distribusi barang dan piutang tidak tertagih.

3. Keputusan taktis yang diambil oleh pelaku UMKM dalam rangka mempertahankan usahanya yaitu penerapan kebijakan WFH (Work From Home), pemotongan gaji, pemotongan dan penundaan pembayaran THR (Tunjangan Hari Raya), meminta relaksasi dan restrukrisasi kredit perbankan, mengurangi jumlah produksi serta melakukan inovasi produk atau layanan jasa.

4. Penundaan pengeluaran kas dan efisiensi biaya menjadi alasan utama para pelaku UMKM mengambil beberapa keputusan taktis di masa pandemi covid' 19.

\section{Saran}

Adapun saran yang direkomendasikan peneliti berdasarkan analisis dalam pembahasan sebagai berikut:

1. Para pelaku UMKM hendaknya melakukan evaluasi lebih mendalam terkait pengaruh keputusan taktis yang telah diambil terhadap kesehatan keuangan usaha. Jika keputusan taktis yang telah diambil tidak memberikan dampak positif terhadap keuangan usaha, sebaiknya para pelaku UMKM segera melakukan perbaikan.

2. UMKM yang tidak mengalami dampak buruk akibat pandemi covid'19, bahkan memperoleh peluang usaha yang lebih besar, dapat mengembangkan bisnisnya untuk menangkap peluang usaha tersebut. Pengembangan bisnis tentunya memerlukan analisis terlebih dahulu sehingga diharapkan memberikan keuntuangan lebih besar.

\section{Keterbatasan Penelitian}

Keterbatasan dalam penelitian ini adalah: 
1. Peneliti hanya melakukan penelitian kepada 5 (lima) pelaku UMKM di wilayah Daerah Istimewa Yogyakarta. Jika penelitian dilakukan dengan lebih banyak responden/informan, data dan hasil penelitian akan lebih bervariasi dan lengkap.

Pada masa pandemi covid'19 ini, wawancara kepada para responden/informan pelaku UMKM sangat terbatas, dan tidak bisa melakukan wawancara langsung berulang kali untuk melakukan kroscek data. Sehingga peneliti tidak dapat melihat langsung bahasa tubuh para responden dalam menggali data untuk menguatkan data penelitian.

\section{DAFTAR PUSTAKA}

Antonius Purwanto. Ujian UMKM Menahan Korona. 2020. Diakses pada https: //kompas.id/ baca/ riset/ 2020/ 03/31/ujian-umkm-menahan-korona/

Aknolt Kristian Pakpahan. 2020. COVID-19 dan Implikasi Bagi Usaha Mikro, Kecil, dan Menengah. Diakses pada https://scholar.google.com

Eka Budiayanti. 2020. Dampak Virus Corona terhadap Sektor Perdagangan dan Pariwisata Indonesia. Jakarta: Bidang Ekonomi dan Kebijakan Publik. Vol XII, No. 4/III/Puslit/Februari/2020.

Estro Dariatno Sihaloho. 2020. Dampak Covid-19 terhadap Perekonomian Indonesia. Diakses pada https://scholar.google.co.id

Hanoatubun, S. 2020. Dampak Covid - 19 terhadap Prekonomian Indonesia. EduPsyCouns: Journal of Education, Psychology and Counseling, 2(1), 146-153. Retrieved from https://ummaspul.ejournal.id/Edupsycouns/article/view/423

Krismiaji dan Y Anni Aryani. 2011. Akuntansi Manajemen. Jogjakarta: UPP STIM YKPN. Luthfia Yuli Kurniawan. 2019. Konsep Pengambilan Keputusan. https://osf.io/y2nk9/download/?format=pdf

Miles, M.B, Huberman, A.M, \& Saldana, J. 2014. Qualitative Data Analysis, A. Methods Sourcebook, Edition 3. USA: Sage Publications. Terjemahan.

Peraturan Otoritas Jasa Keuangan (POJK) Nomor 11/POJK.03/2020 tentang Stimulus Perekonomian Nasional.

Rail Agis Bahtiar dan Juli Panglima Saragih. 2020. Dampak Covid-19 terhadap Perlambatan Ekonomi Sektor UMKM. INFO: Kajian Singkat terhadap Isu Aktual dan Strategis. Vol XII, No.6/III/Puslit/Maret/2020.

Rio Cristiawan. 2020. Relaksasi Kredit: Rescheduling atau Restrukturisasi? Diakses pada https://hukumonline.com 
Rizki Caturini. 2020. Ini Strategi Bertahan bagi Pelaku UKM di Tengah Penjualan Tertekan Corona Diakses pada https://kontan.co.id.

Slamet Sugiri Sodikin. 2015. Akuntansi Manajemen. Jogjakarta: UPP STIM YKPN.

Sugiyono. 2014. Metode Penelitian Kuantitatif, Kualitatif, dan R\&D. Bandung: Alfabeta.

Undang-Undang No. 20 Tahun 2008 pasal 6 tentang Usaha Mikro, Kecil dan Menengah. Diakses pada https://www.depkop.go.id

Yin, R. K. 2008. Studi Kasus, Desain \& Metodologi. Jakarta: Raja Grafindo Persada.. 